\title{
REGULATING OCEAN SHIPPING: POWERS AND PROBLEMS OF THE FEDERAL MARITIME COMMISSION
}

The United States is burdened with vessel operating costs far higher than any other maritime nation. This is primarily the result of high wage scales. ${ }^{1}$ The comparative strength of United States maritime companies has, since World War II, dimmished to the extent that currently only ten per cent of all United States foreign trade is carried in United States vessels. ${ }^{2}$ Considerations of national defense, national pride and commercial prudence have led to a national shipping policy of supporting our merchant marine by subsidies and other promotional devices enabling United States carriers to create a competitive capability, and by regulation of shipping rates to maintain that capability. ${ }^{3}$ Carriers are not the only interests intended to be protected by our regulatory policy; reasonable shipping rates benefit the entire population, as importers, exporters, manufacturers and consumers. ${ }^{4}$

The present rate structure of the maritime industry also presents serious problems. Substantial disparities exist between the cost of shipments to and from the United States, and also between the cost of shipments from the United States to third markets as compared with costs from other exporting countries to those third markets. ${ }^{5}$ For example, the cost of shipping steel plates to Japan from a United States Pacific coast port is 27 dollars per ton, while the import rates on the same route for steel plates is 15 dollars per ton. ${ }^{6}$ The freight rates to export canned fruit juice from the United States Atlantic coast ports are 38 dollars per ton, whereas import rates are approximately 19 dollars per ton. ${ }^{7}$ To ship a plasticizer from New York to Veracruz, Mexico, a distance of 1973 nautical miles, the cost is 54 dollars per ton; the same product shipped from Germany to Veracruz, a distance of 5381 nautical miles, travels for 43 dollars per ton. ${ }^{8}$ These rates are established and maintained by associations of shipping companies called conferences. In the United States responsibility for control of rates in ocean shipping is vested in the Federal Maritime Commission. ${ }^{0}$ This Comment will examine briefly the maritime industry and the regulatory powers vested in the Commission by the Shipping Act of $1916,,^{10}$ analyze jurisdictional objections

1 Staff of Subcomm. No. 5, House Comar. on the Judictary, 87 th Cono., 2d Sess., Ocean Freight Industry 25-26. (Comm. Print 1962), heremafter cited as Celler Repgrt.

2 Id. at 37. This participation of American vessels in American foreign trade is a significant reduction from the $25 \%$ share immediately prior to World War II, and the nearly $60 \%$ share immediately after the war. $I d$. at 41 .

3 Id. at 25-26.

4 See Jones, Antitrust and Specific Economic Regulation, 19 A.B.A. Secr. Antrrrust Law 261, 265 (1961).

5 These disparities are possibly significant factors in the United States' current balanceof-payments difficulties. See Hearings on Discriminatory Ocean Freight Rates and the Balance of Payments Before the Joint Economic Committee, 88th Cong., 1st Sess. (1963).

6109 Conc. Rec. 11915 (daily ed. July 15, 1963).

T 1d. at 11917.

8 Id. at 11917-18.

9 IIereinafter referred to as FMC. The shipping industry has been regulated, in turn, by the U.S. Shipping Board (1916-1933); the U.S. Shipping Board, Department of Counmerce (1933-1936); the U.S. Maritime Conmission (1936-1950); the Federal Maritime Board (1950-1961); and, at present, the Federal Maritime Commission, established by Reorganization Plan No. 7 of 1961, eff. Aug. 12, 1961, 26 Fed. Reg. 7315, 75 Stat. 840 (1961). 1039 Stat. 728 (1916). 
to the exercise of those powers over foreign shippers, and evaluate the practical difficulties presented by a vigorous regulatory program. Finally, an alternative method of regulation through the development of "neutral bodies" within the industry will be presented and discussed.

\section{THE MARITIME INDUSTRY AND THE SHIPPING ACT}

The most sigmificant economic problem of the maritime industry is its continuing susceptibility to cutthroat competition. ${ }^{11}$ The industry is seriously overtonnaged (that is, there is more space available than cargo to fill it). The volume of freight moving in one direction often exceeds the amount of cargo available for return trips. ${ }^{12}$ Most ocean freight is carried by ships sailmg on fixed schedules and routes ("liners"); ${ }^{13}$ shipowners who are committed to making a particular voyage would prefer to carry some or all of the cargo at unremunerative rates rather than sail partially empty, so long as their marginal costs are defrayed by the rates charged.14 A ship operator in such a position is likely to undercut competitors' rates. This act may be met by a similar reduction in competitors' rates, with a rate war resulting.

The conference system was developed to curb this possibility of disastrous competition. Conferences of shipping lines have existed since $1875,{ }^{15}$ and are widespread throughout the maritime industry. ${ }^{16} \mathrm{~A}$ conference is a voluntary association of shipping lines the purpose of which is to restrict or eliminate competition within a given geographic area (trade), principally by controlling rates, but also by fixing saiking routes and schedules, by pooling cargo or earnings, or by sharmg losses. ${ }^{17}$ To protect its members from outside competition, the conference may use "dual-rate contracts," whereby shippers who obligate themselves to use only conference vessels are given lower rates than other shippers. ${ }^{18}$ Other meth-

11 For an extensive discussion of the economics of the maritime industry, see Marx, InTERNATIONAC SHIPPING CaRTEIS 7-44 (1953), hereinafter cited as MARX.

12 MarX 30 . This condition can be due to a difference in total volume of freight moving in each direction, or to predominance of certain types of cargo. If a large percentage of imports to one country is in bulk form, as wheat, and the exports in general freigbt, the tramp which imports the bulk cargo becomes a competitor for general freight on the return trip. Id. at 188 .

13 Tramps and nonconference liners represent the balance of the ocean freight trade. A trainp is a vessel with no fixed schedule or itinerary, which is able to enter a port where cargo is available, contract a cargo without reference to conference rates, and remain until it has a full eargo. Marx 7 n.1.

14 See Ferguson, Lerner, McGee, Or, Rapping \& Sobotra, The Economic Valde of THE UnIted States Mercenant Marine 263-64 (1961).

15 Marx 46.

16 CExIER REPORT 49. Currently there are more than 100 conferences in the foreign coinmerce of the Urited States, the membership of which numbers approximately 24 Americanflag hines and 270 foreign lines. Id. at 52.

17 See Marx 3; Celter Report 95.

18 See CeILER REPORT 185; MARX 202. See also Dodds, Legality of Shipper Tying Arrangements in Ocean Commerce, 23 U. PITT. L. REv. 933, 940-41 (1962). When conferences were first established, the tying device used was the "deferred rebate," by which a shipper paid the normal rates for a given period, and if he continued "loyal" for a further period, he received a rebate on his payments for the first period. See MARx 201-02. This system of deferred rebates has been unlawful in the United States foreign trade since 1916, but is still used in trade not entering this country. Celler REPORT 185. 
ods of restricting competition are often set out in the basic conference agreements, and include minimum loading and discharging requirements, port equalization and differential rates, and currency restrictions. ${ }^{10}$

Conferences are said to provide stability and uniformity of rates and services, and to protect weaker lines and the industry in general from the debilitating effects of rate wars. ${ }^{20}$ While these "advantages" are not universally accepted, ${ }^{21}$ it is undoubtedly true that the Shipping Act of 1916, with the 1961 amendments, constitutes congressional acceptance of the conference system in ocean shipping.

From their inception in 1875 until 1916, when legislation was first enacted, conferences were the subject of investigation and appraisal in the United States and abroad. ${ }^{22}$ A House committee, after lengthy investigation, issued a report recommending continuance of the conference system, witl supervisory authority placed in a government agency. ${ }^{23}$ In 1916, the Shipping Act was enacted, adopting in essence the House committee recommenclations. ${ }^{24}$ Two provisions are central to the Act. Section 14 prohibits a "common carrier by water" from paying deferred rebates, using "fighting ships," ${ }^{25}$ retaliating against a shipper for complaining or for using another carrier, and making any unfair contract with any shipper or unjustly discriminating against any shipper. ${ }^{26}$ Section 15 requires every "common carrier by water" to file with the Federal Maritime Commission any agreement fixing rates, limiting competition, poohing earnings, losses, or traffic, or providing for an "exclusive, preferential, or cooperative working arrangement." ${ }^{\prime 2}$ The filing requirements are compreliensive, extending to virtually every agreement made by a carrier with another person in the inclustry. ${ }^{28}$ The Commission may disapprove, cancel, or modify any agreement found to be "unjustly discriminatory or unfair as between carriers, shippers, exporters, importers, or ports, or between exporters from the United States and their foreign competitors, or to operate to the detriment of the commerce of the United States, or to be contrary to the public interest, or to be in violation of this chapter, and shall approve all other agreements ...."29 Approved agreements are exempt from the operation of the antitrust laws. ${ }^{30}$ The conference system requires such exemption smce. the agreements used, especially those fixing rates, would otherwise violate the Sherman Act. ${ }^{31}$

\footnotetext{
10 See Cexier Report 95-126.

20 See MARX 56-62.

21 See MarX 291; Celler Report 385; McGee, Ocean Freight Rate Conferences and the American Merchant Marine, 27 U. CHr. L. REv. 191 (1960).

22 See Dodds, supra note 18, at 935-38; MARX 45-67; Celler Report 6-13.

23 House Comm. on the Merchant Marine and Fisheries, Steamship Agreements and Applications in the American Foreign and Domestic Trade, H.R. Doc. No. 805, 63d Cong., 2d Sess. (1914).

24 Celler Report 13.

25 A "fighting ship" is a vessel scheduled to depart on the same day, on the same route, as a competing vessel, with rates quoted low enough to deprive the competitor of cargo. CELIER REPORT 10.

2839 Stat. 733 (1916), 46 U.S.C.A. \& 812 (Supp. 1962).

2739 Stat. 733 (1916), 46 U.S.C.A. $\$ 814$ (Supp. 1962).

28 The Federal Maritime Board gave section 15 such a broad reading. See 25 Fed. Reg. 3601 (1960).

2946 U.S.C.A. \& 814 (1962).

3039 Stat. 734 (1916), 46 U.S.C.A. § 814 (1962).

31 See Thomsen v. Cayser, 243 U.S. 66 (1917); United States v. Trans-Missouri Freight Ass'n, 166 U.S. 290 (1897).
} 
In 1961 after three years of investigation and hearings, ${ }^{32}$ Congress passed several amendments to the Shipping Act. ${ }^{33}$ These amendments reaffirmed congressional acquiesence in the conference system as it existed from 1916 to 1961 by approving the dual-rate contract, and added only minor regulatory "teeth" to the Shipping Act.

To carry out its statutory responsibilities, the FMC has an adequate arsenal of powers..$^{34}$ Section 14a of the Shipping Act provides for the exclusion from United States ports of foreigu ships or lines during the continuance of certain violations of the act. ${ }^{35}$ Civil penalties or criminal fines are provided for specific violations. ${ }^{36}$ The most significant power of the FMC, however, is its ability to disapprove, cancel, or modify any conference agreeinent found to "operate to the detriment of the commerce of the United States, or to be contrary to the public interest. ${ }^{137} \mathrm{~A}$ penalty of 1000 dollars per day is provided for carrying out an unapproved or disapproved agreement. ${ }^{38}$ The FMC nust apply the same standard in deciding whether to approve dual-rate contracts filed with it, and in addition has the power to require insertion in those contracts of provisions it deems desirable. ${ }^{30}$ The FMC may also alter any rate or charge found to be "unjustly discriminatory between shippers or ports, or unjustly prejudicial to

32 The investigations were precipitated by Federal Mar. Bd. v. Isbrandtsen Co., 356 U.S. 481 (1958), in which the Supreme Court declared dual-rate contracts to be prohibited by the Shipping Act, after 40 years of approved usage by the conferences. Congress immediately passed legislation which suspended the effect of the Court's decision. 72 Stat. 574 (1958), 46 U.S.C. $\$ 812$ (1958). Two Congressional committees, the House Committee on Merchant Marine and Fisheries and the Antitrust Subcommittee of the House Committee on the Judiciary, undertook the study of the shipping industry and the Federal Maritime Board. The committees uncovered numerous examples of abuse and violations by the industry, and ineffectiveness on the part of the Federal Maritime Board and its predecessors. Indeed, one of the chapters of the Antitrust Subcommittee's Report (Celler Report) is entitled: "The Federal Maritime Board-A Study in Desultory Regulation." Cexter REPORT 321. For a broader discussion of the history of this legislation, see Dodds, supra note 18.

3375 Stat. 762 (1961), 46 U.S.C.A. $\$ \S 801-42$ (Supp. 1962). See FuldA, CoMrpeTITION IN the Regulated Industries: Transportation 310-37 1961).

34 Outside the area of regulatory activity, of course, is the power of the President to close Umited States ports to a particular ship, line, conference of lines, or country-a power that so obviously invites retaliatory measures and charges of violation of international law that it is unlikely to be used except in situations of overriding importance.

3541 Stat. 996 (1920), 46 U.S.C. $\$ 813$ (1958).

30 E.g., 46 U.S.C. $\S \S 812,815,820,831$ (1958), and 46 U.S.C.A. $\$ \S 814,817,817$ b, 817c (Supp. 1962).

3739 Stat. 734 (1916), 46 U.S.C.A. $\$ 814$ (Supp. 1962). Once an agreement has been approved, it is still subject to disapproval if it does not continue to meet these criteria, or on a finding of inadequate policing or of failure to maintain procedures for dealing with shippers' complaints and requests. Ibid.

s8 Ibid.

3975 Stat. 762 (1961), 46 U.S.C.A. § 813a (Supp. 1962). In order to gain FMC approval of a dual-rate contract, there must be included certain specific safeguards for shippers, including a maximum "spread" of $15 \%$ between the rates charged contract and non-contract shippers. Ibid. Eacl carrier and conference must file with the FMC, and keep available to the public, tariffs containing its current rates in all Umited States trade, inust not carry out any rate mcrease until 30 days after filing, and inust adhere to its filed tariffs. 75 Stat. 764 (1961), 46 U.S.C.A. $\$ 817$ (Supp. 1962). In addition to ineeting these requirements, carriers must not give undue preference to any person, locality, or type of traffic; allow any shipper to get lower rates by false billing or other false reports; or imduce any marine insurance company to discriminate on insurance rates. 39 Stat. 734 (1916), 46 U.S.C. \& 815 (1958). 
exporters of the United States as compared with their foreign competitors." ${ }^{10}$ This power of alteration is limited to unequal rates, and does not extend to rates that apply equally to all shippers, ports, importers, or exporters. The FMC can disapprove, but not alter, any rate it finds to be so unreasonably high or low as to be detriniental to United States commerce. ${ }^{41}$ The Commission may investigate possible violations of the act, either on complaint or on its own motion. ${ }^{42}$ It may require periodic or special reports by any carrier, including documents, records, and accounts, ${ }^{43}$ and it can subpoena witnesses, books, documents and records from any place in the United States. ${ }^{44}$ Finally, the FMC is given explicit authority to make such regulations "as may be necessary to carry out the provisions of [the Shipping Act]."45

II

\section{JURISDICTION OVER FOREIGN SHIPPING LINES}

The ultimate sanctions provided by the Shipping Act are criminal fines and possible exclusion from United States ports. The majority of the carriers engaged in United States foreign commerce are foreign-flag vessels, ${ }^{46}$ not "citizens" of the United States and therefore not generally subject to United States law. The international law concept of open ports ${ }^{47}$ is often advanced as prohibiting unilateral regulation of ocean shipping. Proponents of this view argue that it would "violate international law" if United States courts, seeking to enforce FMC orders or trying Shipping Act violations, asserted jurisdiction ${ }^{48}$ over foreign lines for reasons other than those involving the "peace of the port" or other internationally accepted bases. They point out that most of the documents, records, and accounts of foreign limes are located outside the United States, that most of the conference agreements are made outside the United States, that many conference headquarters and officers are located outside the United States, that

4039 Stat. 734 (1916), 46 U.S.C. \& 816 (1958).

4175 Stat. 765 (1961), 46 U.S.C.A. \$ 817 (Supp. 1962).

4239 Stat. 736 (1916), 46 U.S.C. $\$ 821$ (1958).

4339 Stat. 736 (1916), 46 U.S.C. $\$ 820$ (1958).

4439 Stat. 737 (1916), 46 U.S. C. $\$ 826$ (1958). The Commission may seek the assistance of the federal courts for enforcement of a Commission order other than for the payment of money, with the attendant powers of the federal courts to deal with failures to comply. 39 Stat. 737 (1916), 46 U.S.C. $\$ 828$ (1958).

4575 Stat. 766 (1961), 46 U.S.C.A. $\$ 841$ a (Supp. 1962).

46 See note 16 supra.

47 The prevailing international notion of "open ports" is part of the widely-accepted tradition of freedom of the seas. Kharasch, Conferences of Carriers by Sea: Freedom of Rate Fixing, 23 J. AIR L. \& CoM. 287, 288 (1956). Although a nation retains sovereignty over its ports, "there exists a general license under which maritime commercial shipping may pass freely through territorial waters, enter ports to refuel, and pick up or discharge cargo and passengers." Thomas \& Thomas, Theories of Trade in International Law and Their Infhtence on Air Commerce, 7 Sw. L.J. 219, 236 (1953). A country can refuse admission to ships that fail to adhere to its laws, or otherwise endanger the "peace of the port," but not otherwise. Wildenhus's Case, 120 U.S. 1, 12 (1887). A government attempting to exclude parts of the maritime industry is therefore faced with serious international consequences if its reasons are not widely accepted as valid. It cannot, for example, exclude foreign shipping because enough maritime service is already present.

48 It should be noted that no problems of personal jurisdiction are involved. All of the shipping lines are "present" for jurisdictional purposes, as are most of the conferences. 
America's own lines constitute only a handful of those active in ocean commerce, and that many of the activities proscribed by the Shipping Act, or regulated under it, are lawful in other nations. The foreign limes also argue that they are possibly subject to varying commands from several different countries, and that any conflict would be irreconcilable and manifestly unfair. ${ }^{49}$ Support is sought from cases involving antitrust action, particularly the case of American Banana Co. $v$. United Fruit $\mathrm{Co}{ }^{50}$ which is commonly regarded as a landmark enunciation of the "territorial" primciple of penal jurisdiction, a principle which restricts the effect of a nation's laws to acts done within its territorial limits, at least so far as non-citizens are concerned. ${ }^{51}$ The court enunciated the territorial principle by saying:

[T]he general and almost universal rule is that the character of an act as lawful or unlawful must be determined wholly by the law of the country where the act is done. . . . For another jurisdiction, if it should happen to lay hold of the actor, to treat him according to its own notions rather than those of the place where he did the acts, not only wonld be unjust, but would be an interference with the authority of another sovereign, contrary to the comity of nations, which the other states concerned justly might resent.52

Subsequent decisions have limited American Banana to its facts, narrowed the sweep of its broad language, and have thereby expanded the reach of United States regulation ${ }^{53}$ to the point that the territoriality concept encompasses acts done abroad by foreiguers which involve and affect United States commerce. ${ }^{54}$ A federal court of appeals lias recently said:

While Congress has no power to regulate commerce in ... [foreign nations], it does have power to regulate commerce "with foreign Nations, and among the several States." Const. art. I, \& 8, cl. 3. This power is now generally interpreted to extend to all commerce, even intrastate and entirely foreign commerce, which has a substantial effect on commerce between the states or between the United States and foreign countries. 55

In United States v. Holophane Co., ${ }^{56}$ a case involving an alleged violation of the Sherman Act by dividing world niarkets among an American corporation and two foreign corporations, it was argued that asserting jurisdiction over acts done abroad was a violation of international law. Neither of the foreign companies marketed in the United States, and neither was a party to the action. The district court ruled that it had jurisdiction over the subject matter of the marketing (1963).

49 See N.Y.Times, Feb. 16, 1962, p. 58, col. 5 (Eastern ed.); 149 ShIPPINg WorId 615

50213 U.S. 347 (1909).

51 See Brewster, AnttTrust and AMerican Bustness Abroad 65-75 (1958); Fugate, Foreign CoMcmerce aNd THe ANitirust Laws 20-55 (1958). In American Banana, one American corporation sued another for treble damages under the Sherman Act, complaining that United Fruit had monopolized the banana trade from Central America to the Umited States, by persuading Costa Rica to use its militia to eject the plaintiff from the country. The Court refused to hold the conduct subject to the Sherman Act.

52213 U.S. at 356.

53 See, e.g., United States v. Sisal Sales Corp., 274 U.S. 268 (1927); Thomsen v. Cayser,

243 U.S. 66 (1917); United States v. Aluminum Co. of Am., 148 F.2d 416 (2d Cir. 1945).

54 BREwSTER, op. cit. supra note 51, at 74; FUGATE, op." cit. supra note 51, at 31 .

55 Vanity Fair Mills, Inc. v. T. Eaton Co., 234 F.2d 633, 641 (2d Cir.), cert. denied,

352 U.S. 871 (1956).

56119 F. Supp. 114 (S.D. Ohio, 1954). 
agreement, and the Supreme Court rendered a unanimous memorandum affirmance. ${ }^{57}$ There now seems little doubt that United States courts will assert jurisdiction over acts done abroad substantially afiecting United States commerce, in accordance with the intent of Congress under the Sherman Act. ${ }^{58}$ The antitrust cases, therefore, rather than supporting the position that unilateral regulation of international commerce violates international law, provide in an analogous area a strong precedent for vigorous activity by the FMC.

Trade with Canada and with or through Mexico has given rise to roughly similar problems of jurisdiction over international carriers. In an early antitrust case, ${ }^{59}$ the Supreme Court upheld the jurisdiction of the United States courts over a monopolistic agreement between American and Canadian companies involving commerce from the northwestern United States to parts of Canada and to Alaska. The Court noted that to deny jurisdiction would put the agreement beyond the control of either Canada or the United States, and then said, "If we may not control foreign citizens or corporations operating in foreign territory, we certainly may control such citizens and corporations operating in our territory, as we undoubtedly may control our own citizens and our own corporations."

The Interstate Commerce Act applies to railroads operating between the United States and a foreign country to the extent that the transportation takes place in the United States, ${ }^{61}$ and to motor carriers operating between any place in the United States and any place in a foreign country. ${ }^{62}$ The Interstate Commerce Commission has continually asserted jurisdiction over commerce crossing our borders by maintaining the right to order United States carriers to cease and desist from participation in joint international rates found to be unreasonable. ${ }^{03}$ Further, the Commission has shown little hesitancy in applying the broad language of the Interstate Coinmerce Act to foreign carriers whose operations affect United States commerce. ${ }^{64}$ It has, for example, clained jurisdiction over a Canadian sightseeing line that began and ended its trips in Canada after travelling

57352 U.S. 903 (1956). The affirmance prompted one writer to say that it made "extremely short shrift" of the argument that international law prevents the assumption of jurisdiction by American courts in such a situation. Oliver, Extraterritorial Application of United States Legislation Against Restrictive or Unfair Trade Practice, 51 Akc. J. INT'x L. 380, 383 (1957). See Steele v. Bulova Watch Co., 344 U.S. 280 (1952); United States v. Aluminum Co. of Am., 148 F.2d 416 (2d Cir. 1945); and United States v. Watchmakers of Switzerland Info. Center, Inc., Trade Reg. ReP. (1963 Trade Cas.), \} 7 0 6 0 0 \text { (S.D.N.Y.Dec. 20, 1962). }

58 Fugare, op. cit. supra note 51, at 54. See Nitschke, Some Antitrust Problems in Foreign Trade, 37 Mice. S.B.J. 19 (1958), where the author, speaking of jurisdiction over foreign companies, said: "[I]t is important to note how enormously long is the arm of the antitrust law, from the standpoint of grand jury subpoenas and discovery as well as from the stand. point of service of process and liability to suit." Id. at 25 .

50 United States v. Pacific \& A. Ry. \& Nav. Co., 228 U.S. 87 (1913).

60 Id. at 106.

6124 Stat. 379 (1887), 49 U.S.C. $\$ 1$ (1958).

6249 Stat. 543 (1935), 49 U.S.C. $\$ 303$ (1958).

63 Chas. H. Lilly Co. v. Great No. Ry., 298 I.C.C. 407 (1956); Black Horse Tobacco Co. v. Illinois Cent. R.R., 17 I.C.C. 588 (1910). The courts seemingly have approved tbe I.C.C.'s practice of disapproving international joint rates. See Louisville \& N. Ry. v. Sloss-Sheffield S. \& I. Co., 269 U.S. 217, 232 (1925) ; World Publishing Co. v. Davis, 16 F.2d 130, 133 (N.D. Okla. 1926). The I.C.C. itself, however, has disclaimed power to suspend an international joint rate. Cyanamid and Cyanide from Niagara Falls, 155 I.C.C. 488 (1929).

64 For a discussion of I.C.C. activity in international comnerce, see Anderson, ExtraTerritorial Jutrisdiction and the Interstate Commerce Commission, 30 I.C.C. Prac. J. 569 (1963). 
in the United States, ${ }^{65}$ and in one case asserted control over a joint rate for a route approximately 200 miles long, of which one mile was within the United States. ${ }^{60}$

If the United States antitrust policy can be applied to monopolistic or restrictive activity devised abroad and enforced against persons over whom the Umited States has in personam jurisdiction, because the acts "substantially affect" United States commerce, then there should be even less liesitancy to apply United States shipping policy to foreign lines. ${ }^{67}$ Many of the conference agreements are entered into in the United States, thousands of contracts with American shippers are made in the United States by conferences, and the vessels of the foreign conference members enter American ports regnlarly, carrying ninety per cent of United States ocean commerce. Obviously, the rates cliarged and service provided in our ocean trade substantially affect our commerce. The language of the Shipping Act strongly indicates that Congress intended the act to apply equally to foreign and American vessels, and that the FMC and its predecessors were delegated jurisdiction over foreigu carriers. ${ }^{68}$ This conclusion was reached early in the history of the act ${ }^{69}$ It seems clear that United States shipping policy could be applied to at least the same extent as the antitrust laws, for a large number of the acts souglit to be regulated under our shipping policy are done inside United States territory. The application of our slipping regulation laws, lowever, is subject to the previously mentioned open ports problem, ${ }^{70}$ and to practical political problems of regulation and enforcement.

65 Inglis Common Carrier Application, 31 M.C.C. 209 (1941); Cripps Common Carrier Application, 24 M.C.C. 19 (1940).

60 Great Lakes Ship Owners Ass'n v. Canadian Pac. Ry., 299 I.C.C. 311 (1956).

67 In two very recent cases, McCulloch v. Sociedad Nacional de Marineros de Honduras, 372 U.S. 10 (1963), and Incres S.S. Co. v. International Mar. Workers Umion, 372 U.S. 24 (1963), the Supreme Court has demied the extension of National Labor Relations Board jurisdiction to foreign ships employing foreign seamen while in Umited States ports. Relying primarily on the fact that the "internal management and affairs" of the ship would be affected, the Court declined to interfere with the "well-established rule of international law that the law of the flag state ordinarily governs the internal affairs of a ship," in absence of any elear congressional intent so to interfere. 372 U.S. at 21. Throughout the opinion the Court seemed acutely aware of the international ramifieations of the issues presented. Id. at 17, 19, 21. It should be noted that in the inajor case, an assertion of jurisdiction would have brought American law into direct conflict with the law of the flag state, $i d$. at 21 , a situation unlike that presented in the regulation of the shipping industry, where there is no obvious superior interest elsewhere which can fill the void of United States refusal to act. It could also be argued that the wages paid foreign seamen on foreign vessels are not as significant to the commerce of the United States as are the rates charged for the great majority of American occan-borne exports and imports, and therefore the lesser interest does not justify attempting to extend the effect of United States laws. Furthermore, the Court indicated that Congress could prescribe such extension if it so desired. $I d$. at 17 .

08 The act apphes to "a common carrier ... engaged in the transportation by water of passengers or property between the United States . . . and a foreign country, whether in the import or export trade." 39 Stat. 728 (1916), 46 U.S.C.A. $\$ 801$ (Supp. 1962). Further provisions of the act which indicate intent to subject American and foreign lines equally to regnlation are the defimition of "person" as including corporations, partnerships, and associations existing or authorized under the laws of the United States or any foreign country, 39 Stat. 728 (1916), 46 U.S.C.A. $\$ 801$ (Supp. 1962); and the exclusion provision applying to "any person, not a citizen of the United States and engaged in transportation by water of passengers or property." 41 Stat. 996 (1920), 46 U.S.C. $\$ 813$ (1958).

60 Compagnie Generale Transatlantique v. American Tobacco Co., 31 F.2d 663, 665-66

(2d Cir.), cert. denied, 280 U.S. 555 (1929).

70 See note 47 supra and acconipanying text. 


\section{III}

\section{PRACTICAC PROBLEMS OF REGULATION}

Although it is clear that Congress has granted broad powers to the FMC, and that there is ample precedent for use of those powers, ${ }^{71}$ the question remains whether vigorous activity by the FMC against foreign carriers is politically feasible. The possibility of international conflict is not to be ignored. For example, the British government has on several occasions made explicit its feeling toward American regulation of industry, whether through direct antitrust action or through an agency such as the FMC. A high British official has recently said:

[W] cannot accept the principle that any one country, however powerful and however friendly, should unilaterally regulate international shipping. I have stated this before and $I$ state it again, and it is a view shared by the leading inaritime European nations and also by the Japanese Government.72

In the antitrust area, the British government has asserted sovereign immunity for a British company in an attempt to thwart an investigation of an international oil cartel, ${ }^{73}$ and an English court has acidly rejected the attempt of an American court to exercise "extraterritorial jurisdiction." ${ }^{\text {"4 }}$ Great Britain is not the only

71 In addition to activities in the antitrust and land transport areas, the FMC might look for precedents to the activity of the Civil Aeronautics Board (CAB) in regulation of international air commerce. The physical similarities of the international aviation and shipping industries are obvious. Furthermore, Congress has recognized the need for associations of air carriers to fix rates and has granted antitrust exemption to those associations. 72 Stat. 770 (1958), 49 U.S.C. $\S 1384$ (1958). The $\mathrm{CAB}$ is not burdened with the freedom of access to the United States that confronts the FMC, however, for international law broadly recognizes the sovereignty of a nation over its airspace. Kharasch, Conferences of Carriers by Sea: Freedom of Rate Fixing, 23 J. AIR L. \& CoM. 287, 288 (1956). Subject only to treaties and other agreements such as reciprocal landing rights, a nation may control the entry of aircraft into its territory. However, action of the $\mathrm{CAB}$ is subject to the specific limitation that all acts affecting foreign air carriers must be approved by the President of the United States, 72 Stat. 782 (1958), 49 U.S.C. $\$ 1461$ (1958), and also that the CAB must act consistently with any trcaty or other international obligation currently binding on the United States. 72 Stat. 797 (1958), 49 U.S.C. $\S 1502$ (1958). Like the FMC, the CAB has no power to set rates in international commerce, and can only disapprove or cancel agreements found detrimental to United States commerce, lacking the FMC's power to modify such agreements. Bebchick, The International Air Transport Association and the Civil Aeronautics Board, 25 J. AIR. L. \& CoM. 8, 11 (1958); Kharasch, supra at 298.

Nevertheless the $C A B$ has been more aggressive in its supervision of the carriers' organization than has the FMC, and the $\mathrm{CAB}$ has found that the organization, the International Air Transport Association, provides a useful vehicle for the assertion of some control over international rates. Bebchick, sulpra at 41 ; Sheehan, The IATA Trafjic Conferences, 7 Sw. L.J. 135, 162 (1953). Although writers have recently been critical of the CAB's vigor, Kittrie, United States Regulation of Foreign Airtines Competition, 29 J. ATR. L. \& Com. 1 (1963); Note, 51 Geo. L.J. 593 (1963), that agency provides an example of forceful regulatory action in a situation analogous to that of the FMC.

72 Statement of Mr. Ernest Marples, Minister of Transport, in the House of Commons. 659 H.C. Des. (5th ser.) 407-08 (1962). See also N.Y.Times, Mar. 16, 1963, p.9, col.4 (Western ed.).

${ }^{73}$ In re Investigation of World Arrangements, 13 F.R.D. 280 (D.D.C. 1952). Sovereign immunity might present a problem in shipping regulation, for some of the foreign lines are government-owned or operated. It seems, however, that under the "restrictive principle" sovereign immunity should not extend to a government's operation of a shipping line. Cf. In re Grand Jury Investigation of the Shipping Indus., 186 F. Supp. 298, 318-20 (D.D.C. 1960).

${ }_{74}$ British Nylon Spinners, Ltd. v. Imperial Chem. Indus, Ltd., [1953] $1 \mathrm{Ch}$. 19. The English court enjoined an English company from taking action directed by an American court. The American court considered carefully the argument of extraterritoriality and concluded that 
country to react. Sparked by United States government attempts to obtain records located in Canada, Ontario passed its Business Records Protection Act,75 prohibiting Canadians from turning over their records, and the Netherlands has an even broader provision, prohibiting subjects from observing "measures or decisions of another State which concern regulations on . . . economic competition practices." "76

Access to business records abroad for investigative purposes has proved to be a problem for the FMC as well as other government agencies. ${ }^{77}$ The FMC attempted to solve this problem by using its power under Section 21 of the Shipping $\mathrm{Act}^{78}$ to require periodic and special reports, specifying that the reports contaim information from, and copies of documents located in, foreign countries. Two courts of appeals upheld this action $;^{79}$ one suggested that the FMC might even use its subpoena power ${ }^{80}$ if process were served within the United States directing the production of documents located abroad over which the person served had control. ${ }^{81}$ Both courts indicated they were not concerned with enforcing the FMC's order, but only with its validity. ${ }^{82}$

It would seem that a wise policy to be followed by the FMC in gaining access to foreign documents would be to allow a showing of good faith attempts by the carrier to provide the records or copies; upon a showing of good faith and inability to comply, the FMC unight, through diplomatic channels, seek access to the desired material at its foreign location by an agent of the Commission or perhaps by a disinterested third person; ${ }^{83}$ upon failure of all these attempts, the Commission should review its previous approval of the basic agreement of the conference, on the theory that an unsupervised conference agreement is not in the public interest, and if necessary, withdraw approval from the conference entirely. As an alternative to disapproval, the Commission might seek the enforcement aid of the federal courts, thereby applying additional pressure since the penalty for failure to comply with orders under section 21 is a forfeiture of 100 dollars per day. ${ }^{84}$ In an action for a monetary penalty, however, the carrier may have a vahid defense because of its inability to comply, while a disapproval threat might cause the other conference inembers to bring persuasive power to bear on the obstructing sovereign. ,

the decree to be rendered did not constitute extraterritorial application of United States law. United States v. Imperial Cleem. Indus., Ltd., 105 F. Supp. 215, 237 (1952). The English court disagreed. [1953] 1 Cl. at 25.

75 ONT. Rev. Stat, C. 44 (1960).

76 Brewster, ANTITRUSt ANd AMTERTCAN Business ABRoAd 483 n.10 (1958). For a general discussion of foreign reactions see id. at 39-51 and Edwards, Regulation of Monopolistic Cartelization, 14 OHто ST. L.J. 252, 263 (1953).

77 See, e.g., Societe Int'l v. Rogers, 357 U.S. 197 (1958) ; Securities and Exchange Commission v. Minas de Artemisa, S.A., 150 F.2d 215 (9th Cir. 1945); In re Investigation of World Arrangements, 13 F.R.D. 280 (D.D.C. 1952).

7839 Stat. 736 (1916), 46 U.S.C. \& 820 (1958).

79 Montship Limes, Ltd. v. Federal Mar. Bd., 295 F.2d 147 (D.C. Cir. 1961) ; Kerr S.S. Co. v. United States, 284 F.2d 61 (2d Cir. 1960). In Montship, however, the court vacated the order because it did not state with sufficient clarity the purpose of the investigation.

8039 Stat. 737 (1916), 46 U.S.C. \$ 826 (1958).

$81295 \mathrm{~F} .2 \mathrm{~d}$ at 153.

82 Id. at $154 ; 284$ F.2d at 64 .

${ }^{83}$ For a more elaborate scheme for gaining access and soothing offended sovereigns' feelings, see Miller, Extraterritorial Effects of Trade Regulation, 111 U. PA. L. REv. 1092, 1114 (1963).

8439 Stat. 736 (1916), 46 U.S.C. \& 820 (1958). 
The problem which presently carries the highest priority for considerationthe large differential between import and export rates ${ }^{85}$ - presents another area in which the FMC might exercise its statutory authority. If after investigation the FMC should decide that the differential is detrimental to the commerce of the United States, it has the power under Section 18 of the Shipping Act to disapprove the rates, and approve more suitable ones when submitted. ${ }^{80}$ The dilemma, however, is im deciding whether to require reduction of export rates, which might ruin the highly subsidized United States lines (or at least increase the amount of subsidies needed), or require an increase in import rates, or some combination of the two moves. An increase in import rates, although seemingly a needless burden upon American importers and consumers, might merit careful consideration if, as has been suggested, the carriers have been "discriminating" against United States exports in cost-allocation accounting. ${ }^{87}$ An alternative attack would be to disapprove the basic conference agreements, relegating the carriers to open rate competition, which would also hit United States carriers the hardest, but might reduce all ocean freight rates to a reasonable level. The carriers might attempt to maintain previous rate schedules, but the FMC has the power to disapprove rates filed by individual carriers as well as conferenceestablished tariffs, ${ }^{88}$ so that an individual carrier's rates can be invalidated, and any sort of mutual action prevented, by a double use of the disapproval power.

Regulatory action directed at carriers for acts other than rate making, as for violations of the Shipping Act or antitrust action upon disapproval of any conference agreement, ${ }^{89}$ must also be carried out with a clear recognition of the

85 Wall Street Journal, Aug. 29, 1963, p. 4, col. 3 (N.Y. ed.). This problem, though currently treated as very critical, may be less important than it seems. The effect of balancing import and export rates is limited by the fact that, assuming that United States vessels continue to carry only $10 \%$ of United States trade, an increase in import rates will produce a greater debit in our transportation balance of payments than the credit produced by a corresponding decrease in export rates. Clones \& McKay, Transportation Transactions in the U.S. Balance of Payments, Survey of Current Business, Aug. 1963, p. 23. However, any decrease in freight rates from the United States to one country, coinpared with the rates there from a third country, will stimulate our overall export trade, the largest credit item in the balance of payments. Id. at p. 28 .

8675 Stat. 764 (1961), 46 U.S.C.A. \& 817 (Supp. 1962).

87 It seems that the practice of conferences has been to consider mbound freight into the Umited States as "back-haul" cargo, thus setting cheaper rates for colnmodities on United States bound ships that would otherwise be returning in ballast to pick up new cargo. The entire charge for overhead costs is assigned to the outbound journey for the Umited States; therefore the "back-haul" rate can be kept lower because only direct cost must be net and any returns in excess of these is considered profit. This being the case, many commodities on several routes have higher rates outbound than the same goods inbound for U.S. ports.

Clones \& McKay, supra note 85 , at p. 28. A reallocation of costs to divide overhead costs equally between export and import journeys presumably would bring about an increase in import rates and a decrease in export rates. However, the vast difference in demand for export space as compared with import demand may require, in an economic sense, a significant differential in rates. See Ferguson, Lerner, McGee, Or, Rapping \& Sobotka, The Economic Value of the UnITEd States Merceaint MarnNe 263-64 (1961).

8875 Stat. 764 (1961), 46 U.S.C.A. $\$ 817$ (Supp. 1962).

89 Under the doctrine of prinary jurisdiction, antitrust action may not be maintained prior to filing of a conference agreement for consideration by the FMC. Far East Conference v. United States, 342 U.S. 570 (1952); United States. Nav. Co. v. Cunard S.S. Co., 284 U.S. 474 (1932). There seems no reason why the antitrust laws would not apply once the adininistrative agency has disapproved the agreement, if the carriers continued to operate under the 
international political realities involved. Exclusion, with its potential retaliatory provocations, should be the last resort; it will lend credibility to the claim that the United States is violating international law by closing its ports. Actions in the federal courts for criminal fines and civil penalties present the best practical sanctions. Even after disapproval of conference agreements, action must be taken to prevent the carriers from continuing to exercise monopoly control. Injunctive and mandatory orders, when issued by the FMC and upheld by the federal courts, should be framed so that resort to foreign courts is unnecessary and that obstructive action by a foreign court upon application by any carrier, conference, or foreign government, is precluded. In short, submission to regulation by the FMC, including compliance with orders reasonably necessary to effectuate that regnlation, should be required of the carriers and the conferences as the price required for the privilege of carrying out monopolistic activity in the United States foreign trade. ${ }^{90}$ This requirement would not do violence to the open ports concept. Refusal to cooperate would probably lead directly to withdrawing approval of conference and rate agreements, exposing these agreements to antitrust prosecutions. If an antitrnst conviction followed, monetary penalties and injunctions-the latter carrying the threat of continuing penalties if violated-would be the probable sanctions. Exclusion from our ports would be at most an extremely unlikely last resort.

\section{IV}

\section{NEUTRAL BODY SYSTEMS: AN ALTERNATIVE METHOD OF ENFORCEMENT}

A possible indirect method of accomplishing increased supervision by the FMC is the "neutral body" system. A neutral body is an independent investigatory and adjudicatory agency, often an accounting firm, ${ }^{91}$ appointed by the conference to police the conference agreement. ${ }^{92}$ Newly amended Section 15 of the Shipping Act requires the FMC to disapprove a conference agreement "on a finding of inadequate policing of the obhigations under it." ${ }^{93}$ Therefore, the

agreement. Private persons would have the right to maintain an action for treble damages for post-disapproval operation of an agreement. See INSTITUTE FOR INTERNATIONAL AND ForeIGN Trade LaW of Georgetown University LaW Center, Conference on Extraterritoriad Effects of Trade Regulation, The Controversy Over "Conferences" in the Shipping Indicstry 6 (1962). The possibility of a treble damages windfall probably would bring about careful scrutiny of carrier operations by competitors and by shippers.

90 The concept of requiring a high standard of compliance with our law in return for a "privilege" is not a novel one. There is ample precedent and sufficient analogy in the Interhandel cases (Societe Int'l v. Brownell, 225 F.2d 532 (D.C. Cir. 1955), cert. denied, 350 U.S. 937 (1956); accord, Societe Int'I v. Rogers, 357 U.S. 197 (1958)).

91 See Celier Report 313; Trans-Pacific Freight Conference of Japan v. Federal Mar. Comm'n, 314 F.2d 928 (9th Cir. 1963).

92 The neutral body's concern is himitcd to violations of the agreement itself-"cheating" on the other conference members. While violations of conference agreements by a member are often also violations of the Shipping Act, as paying deferred rebates, the neutral body represents the conference entity alone, and only imcidentally protects the interests of the shippers and the public, which of course is the FMC's responsibility. Celter Rerort 303.

0375 Stat. 764 (1961), 46 U.S.C.A. \$ 814 (Supp. 1962). Self-policing of conference agreements is a continuing problem, for breaches of conference agreements jeopardize the continued existence of conferences. See CELLER REPORT 303. For a discussion of the self-regulation problems of two conferences, see id. at 306-07. 
Commission might bring its "disapproval club" into action and require the inclusion of neutral body provisions. The FMC has approved some of the neutral body agreements filed with it, ${ }^{94}$ but has insisted upon inclusion of provisions for full reporting to the Commission of activities of the neutral body. ${ }^{95}$ Recently the Commission has promulgated regulations for self-policing systems, ${ }^{00}$ but these regulations do not require the use of a neutral body. The regulations require semi-annual reports from the conference or its policing agent, of the agent's activities, which must include information as to the nature of each complaint received in a reporting period, the action taken on each complaint, the nature of any violations found, and the sanctions imposed. However, the identity of the complaint and the suspected violator need not be included in the report.

The conferences, as night be expected, have voiced some objections to the use of the neutral body system. Chief among the objections is the fear that, after a fine by the neutral body, the FMC's reporting requirements will result in a prosecution for violation of the Shipping Act.97 This fear might be somewhat alleviated, however, by the new reporting requirements of the FMC. Another possible objection to a neutral body system is the cost to the conference of inaintaining such a system. Clearly, the most effective neutral body will be one which combines an accountant's expertise about business records with an intimate knowledge of the shipping industry, and this may prove costly. One possible solution might be use of a large accounting firm which can provide neutral body services to more than one conference, thereby spreading some of the basic costs, as well as adding to the independence of the "policeman."

Another possible objection to use of neutral bodies may be directed to their effectiveness; other methods of self-policing have not been very successful.98 A high degree of integrity in the neutral body and cooperation from conference members and shippers is necessary for effective self-regulation. Only a good faith, widespread trial of the neutral body system will resolve the issue of effectiveness.

Self-policing is an obvious presupposition of Section 15 of the Shipping Act. An effective neutral body scheme night go a long way toward easing at least two of the FMC's more thorny problems-the difficulty of access to documents located abroad and the reluctance of foreigu shipping lines to cooperate with an agency of another country's government. ${ }^{99}$

Recently the FMC has declared invalid a neutral body system on the basis of conflict of interest on the part of the neutral body itself. This was upheld upon review. ${ }^{100}$ The conferences amended their netural body agreements to permit the conflict of interest so long as full disclosure is made; the FMC approved

$94 \mathrm{Id}$. at 307.

95 Id. at 309 .

9628 Fed. Reg. 9257 (1963).

97 See CenLer Report 316.

98 See, e.g., Cetter Report 306-07.

$00 \mathrm{Id}$. at 315 .

100 Trans-Pacific Freight Conference of Japan v. Federal Mar. Comm'n, 314 F.2d 928 (9th Cir. 1963). A member suspected of rebating refused to grant access to its records to the New York correspondent of the conference's neutral body, a Tokyo accounting firm. The member complained that the New York firm was the accountant of a competitor (a conference member), and therefore that the hiring of the Tokyo firm constituted a conflict of interest in contravention of the neutral body agreement. The neutral body levied two fines on the dissident member, who complaimed to the Maritime Coinmission, which vacated the order. The Ninth Circuit Court of Appeals upheld the FMC's act. 
the amendments, ${ }^{101}$ and the conference member opposing the approval filed an appeal with the Circuit Court for the District of Columbia. ${ }^{102}$ The initial disapproval and current uncertainty, viewed in the hight of conference reluctance to accept the FMC's reporting requirements, might well deter the conferences from further adoption of neutral bodies. Indeed, one of the few conferences to adopt a neutral body system has recently dropped it. ${ }^{103}$

Neutral bodies could prove to be a valuable supplement to the FMC's direct powers. To achieve this, the FMC should embark upon a concerted campaign to sell the neutral body idea to the conferences. As an alternative, the Commission might consider amending its rules to require the use of a neutral body, as the only acceptable means of self-regulation. ${ }^{104}$ The Commission should also consider employing the diplomatic process to win the support of other important maritime nations im fostering the development of neutral body systems; the provisions for consultation and consideration under the Treaties of Friendship, Commerce and Navigation might be useful. ${ }^{\mathbf{1 0 5}}$

Along with its advocacy of the neutral body system, the FMC must also make clear that a realistic attitude toward supervising the policing agencies will be adopted. The FMC cannot abdicate its responsibility to the neutral body by allowing its action to be the only penalty imposed in all cases, ${ }^{106}$ but it could provide in its regulations for self-policing systems that the names of the violating lines be included in the semi-annual report only when the line has been penalized two, or perhaps three, times within a year or other appropriate period. Thus, only repeated offenders would be subjected to follow-up investigation by the FMC or the Justice Department. ${ }^{107}$

101 Trans-Pacific Freight Conference of Japan, FMC Dkt. 1095, 32 U.S.L. WeEr 2223 (Oct. $30,1963)$. The neutral body agreement as amended requires disqualification of the neutral body only if it has an interest in the member against whom the complaint is made. The neutral body may continue to function if it has an interest in the member making the complaint, a provision which raises some question of fairness and constitutionahty. See note 107 infra.

${ }^{102}$ States Marine Limes, Inc. v. Federal Mar. Comm'n, appeal docketed, No. 18227, D.C. Cir., Nov. 9, 1963.

10328 Fed. Reg. 6893 (1963).

104 The Commission itself has not decided to require use of a neutral body system as the exclusive acceptable means of self-regulation. "[W]e are not inclined when considering approval to specify the procedures by which the parties seek to insure that each will fulfill its obligations to the others." FMC Dkt. 1095, supra note 101, 32 U.S.L. WEEK at 2224.

$105 \mathrm{~A}$ typical provision is that each party will "accord sympathetic consideration to, and shall afford adequate opportunity for consultation regarding, such representations as the other Party may make with respect to any matter affecting the operation of the present Treaty." Treaty of Friendship, Commerce, and Navigation With Japan, April 2, 1953, art. XXIV, para. 1, 4 U.S.T. \& O.I.A. 2063, T.I.A.S. No. 2863.

106 See Celter Report 319.

107 Two difficult areas involving constitutional rights are presented by the neutral body system. The first is the weight that can be given to neutral body activity by the FMC and the federal courts. It would seem that neutral body action could be only a hint to the FMC or the Justice Department of the need to investigate. Using a neutral body fine or other sanction as conclusive or even prima facie evidence of violation raises serious self-imcrimination questions. For either criminal fine or civil penalty, the United States' case must be independently investigated and established.

The second area of difficulty concerns the relation of a conference member to the neutral body. The economic necessity of conference membership might coerce submission to neutral body process (this coercion is heightened if the FMC requires neutral body policing), and a member might suffer arbitrary action in violation at least of common law rules of fair play, if not in violation of constitutional rights. Cf. Cox, The Role of Law in Preserving Union Democracy, 72 HARv. L. REv. 609, 612-18 (1959). 


\section{CONCLUSION}

In the eyes of many of the nations of the world, the United States is not only trying to promote policies of government control of business by antitrust concepts or regulated-monopoly substitutes which are not widely accepted outside the United States, ${ }^{108}$ but is attempting to do so in a manner which infringes upon the sovereign riglits of other countries. It is clear that application of our laws to international trade must be done with recoguition of the delicate problems involved. Equally clear, however, is our commitment to the principle of regulation in the shipping industry. There is no international body able to regulate the industry. ${ }^{109}$ The regulatory scheme provided by the Slipping Act, and the programs of the FMC to effect that scheme, are not attempts to exercise extraterritorial jurisdiction, but constitute the price required for monopohstic privileges.

Although the statutory authority of the Federal Maritime Commission does not include the power to set rates in foreign commerce, its powers to disapprove unreasonable rates, alter discriminatory rates, and grant reparations to shippers, coupled with the basic powers under section 15 to disapprove, cancel, or modify conference agreements, constitute what an investigating congressional committee called "a large panoply of powers which, if exercised to their fullest, would [be] of sufficient potency to discourage many of the patent abuses currently prevailing in the operation of the conference system in American foreign trade."110 With this authority in the background an intelligent, forceful use of the unofficial powers of persuasion and negotiation can be used to develop an effective regulatory system.

\section{Ralph C. Walker}

108 There are portents of more unanimity with respect to general attitudes about monopolistic practices, however. See, e.g., Gunther, The Problems Involved in Regulating International Restraints of Competition by Means of Public International Law, in 2 CARTEL AND MONOPOLY IN MODERN LAW 579 (1961); Kronstein, The Significance of the Provisions Concerning Restraints of Competition Within the Total Perspective of the European Coal and Steel Conmunity Treaty and the European Economic Community Treaty, in 1 CARTEL AND MONOPOLY IN MODERN LAW 131, 139 (1961).

109 The Inter-Governmental Maritime Consultative Organization, which officially came into being in 1959, is a purely consultative and advisory organization. See INTER-GovERNmental Maritime Consultative Organizatron, Basic Documents 8 (1962); MarX 272-79. 110 CellLer Report 324. 